Walisongo Law Review (Walrev), Vol 1 No. 2 (2019)

DOI: 10.21580/Walrev/2019.1.2.4825

Copyright (C) 2019 Walisongo Law Review (Walrev)

\title{
Sak Uwong Sak Uwit Policy: Environmental Conservation Strategy
}

\author{
Saifudin \\ Afiliasi: Universitas Islam Negeri (UIN) Walisongo, Semarang \\ e-mail: saifudin@walisongo.ac.id
}

\begin{abstract}
Development is one of the contributors to global warming, especially industrial development. Industrial companies in Kendal Regency in 2017 there were 61 companies with 25,385 workers. The phenomenal industry in Kendal Regency lately is a Special Industrial Zone (KIK) known as Kendal Industrial park (KIP). Kendal Industri Park (KIP) is the largest industrial development city in Central Java with a total development size of 2,200 hectares. Kawasan Industri Park (KIP) is a joint venture between two industrial developers in Southeast Asia naming Sembcorp Development Ltd and PT Jababeka Tbk. This paper examines the implementation of the Sak Uwong Sak Uwit (SUSU) policy in Kendal District where the policy is in response to global warming. The focus of this study is the implementation of a policy, so the method used is a juridical-empirical legal research method. The focus of his study is looking at the law in terms of law in action not in law in books. The Sak Uwong Sak Uwit (SUSU) policy can be implemented even though it is not yet maximized. The bride and groom have received information about this policy and implemented it, but it is different from the mother giving birth who did not get information
\end{abstract}


about this policy so that for the mother giving birth the program did not work. This policy has been able to move the community (law as a tool of social engineering) to care for the environment by planting trees. By planting these trees environmental conservation will be created.

Pembangunan menjadi salah satu penyumbang terjadinya pemanasan global (global warming), terlebih pembangunan industri. Perusahaan industri di Kabupaten Kendal tahun 2017 tercatat sebanyak 61 perusahaan dengan 25.385 tenaga kerja. Industri yang fenomenal di Kabupaten Kendal akhir-akhir ini adalah Kawasan Industri Khusus (KIK) yang dikenal dengan sebutan Kendal Industri park (KIP). Kendal Industri Park (KIP) ini merupakan pengembangan kota industri terbesar di Jawa Tengah dengan total ukuran pengembangan mencapai 2.200 hektar. Kawasan Industri Park (KIP) merupakan perusahaan patungan antara dua pengembang industri di Asia Tenggara penamaan Sembcorp Pengembangan Ltd dan PT Jababeka Tbk. Tulisan ini mengkaji tentang implementasi kebijakan Sak Uwong Sak Uwit (SUSU) di Kabupaten Kendal di mana kebijakan tersebut sebagai respon terhadap pemanasan global. Fokus kajian ini adalah implementasi dari sebuah kebijakan, sehingga metode yang yang digunakan adalah metode penelitian hukum yuridis-empiris. Fokus kajiannya adalah melihat hukum dari sisi law in action tidak pada law in books. Kebijakan Sak Uwong Sak Uwit (SUSU) dapat dïmplementasikan meski belum maksimal. Calon pengantin sudah menerima informasi tentang kebïakan ini dan melaksanakannya, namun berbeda dengan ibu melahirkan yang tidak mendapatkan informasi tentang kebjaka ini sehingga untuk ibu melahirkan program ini tidak berjalan. Kebijakan ini sudah mampu menggerakkan masyarakat (law as a tool of social engineering) untuk peduli lingkungan yaitu dengan menanam pohon. Dengan menanam pohon tersebut konservasi lingkungn akan tercipta.

Keywords: law; social engineering; Policy; conservation. 


\section{Introduction}

Environmental damage due to human activities has become a serious problem in all regions. The impact of this environmental damage can be felt by the many disasters that occur such as floods, abrasion, environmental pollution, pollution, and also global warming. The phenomenon of flooding is a threat that always occurs during the rainy season. Flooding does not only occur in the lowlands but also in the highlands. Likewise with abrasion in which many areas are eroded by sea water and force residents to move from these places. Environmental pollution, pollution and global warming are also threats facing humans.

Global warming has become an international issue since several decades ago. Initially many people doubted whether the issue of global warming is true but at this time the impact of global warming has been felt by most of the world community. Among the impacts are the weather is getting hotter, the weather is uncertain, extreme climate change, many floods occur, sea levels rise. This impact is very detrimental to the existence of humans who live in this universe. A stable natural condition will benefit mankind, and vice versa if the natural conditions are not clear, erratic will make people confused and very detrimental to them.

The losses experienced by humans with global warming include natural disasters, difficulty in getting food, and clearly threatening human life. Especially if the ability of ecosystems or communities to adapt to climate change is low. Large temperature increases occur in high latitudes, so that it will cause global environmental changes such as melting of polar ice caps, distribution of natural vegetation, and threatened biodiversity. While the tropics or low latitudes will be affected in terms of crop productivity, distribution of pests and diseases of plants and humans (Murdiyarso, 2005: 19).

Development is one of the contributors to global warming, especially industrial development. Industrial companies in Kendal Regency in 2017 there were 61 companies with 25,385 workers BPS (Kendal, 2018: 203). The phenomenal industry in Kendal Regency lately is a Special Industrial Zone (KIK) known as Kendal Industrial park (KIP). Kendal Industri Park (KIP) is 
the largest industrial development city in Central Java with a total development size of 2,200 hectares (kendalindustrialpark.co.id).

Kawasan Industri Park (KIP) is a joint venture between two industrial developers in Southeast Asia naming Sembcorp Development Ltd and PT Jababeka Tbk. This project is strongly supported by the Government of Indonesia and the Government of Singapore. This project was officially opened on November 16, 2016 by the President of the Republic of Indonesia, Ir. Joko Widodo, and Singapore Prime Minister Lee Hsien Loong. Until now Kendal Industrial Park (KIP) has managed to attract more than 40 tenants from different industries such as food, furniture, stationery, building materials, warehousing, and so on (kendalindustrialpark.co.id).

Phase 1 development of Kendal Industrial Park (KIP) includes golf courses, downtown, shopping, marina cities, food cities, fashion hubs, furniture hubs, high-rise residential development, bungalows (Oxford Dictionary, 2009: 54) uxury, and industrial cluster. This development is the first of its kind in Central Java and even in Indonesia. Kendal Industri Park (KIP) will be an ecosystem operating for years in industrial clusters and independent economic systems (kendalindustrialpark.co.id).

The project's shareholders are Sembcorp Development and PT Jababeka Tbk. Sembcorp Development is a wholly owned subsidiary of Sembcorp industries, which is a Temasek-linked company listed on the Singapore Exchange. Sembcorp Development is a leading developer in Asia with more than 20 years of master planning business track record, land preparation and infrastructure development to turn raw land into urban development (kendalindustrialpark.co.id).

While PT Jababeka Tbk is a company established in 1989. PT Jababeka Tbk is a major developer of cities in Indonesia with business in land development (industrial, residential, commercial, office space, etc.); infrastructure (water supply, wastewater treatment, estate management, electricity, dry port / logistics, etc.), and recreation and hospitality (golf, hotels and resorts, etc.). Jababeka's main development in the City of Jababeka is an integrated 5,600-hectare city in Cikarang, 35 kilometers east of Jakarta. The city of Jababeka has an estimated population of more than 1 million people and is home to more than 1,600 local and multinational 
companies from 30 countries that employ more than 800,000 workers and 4,500 expatriates.

The stages of this project were started in 2012 which was held in that year a joint venture agreement (Panjaitan and Sianipar, 2008: 142). Then continued in the following year, namely 2013-2014 is the construction of infrastructure and the provision of the first phase of land area of 860 hectares. Next year 2014-2015 is to start the construction of factories through the absorption of investors in the power of workers. The next stage is the inauguration of Kendal Industrial Park (KIP). 2020 is the completion of the main infrastructure. And in 2028 the completion of phase 1 (kendalindustrialpark.co.id).

Kendal Regency is inseparable from the threat of global warming. Floods, robs, abrasion, hot weather are problems faced by Kendal Regency. Especially with the large-scale industrial development in Kendal Regency, it will add new environmental problems. Although it is undeniable that industrial development also has a positive impact on economic growth and reduces unemployment, on the other hand if it is not managed properly it will also have negative impacts on the environment such as pollution, hotter weather, flooding due to reduced water absorption.

\section{Research methods}

This study examines the implementation of the Regional Regulation of Sak Uwong Sak Uwit (SUSU) in Kendal Regency. Because what is studied is the application of a rule or policy, the appropriate research method used is the juridical-empirical legal research method. The focus of his study is looking at the law in terms of law in action not in law in books (Hanitijo, 1990: 34).

\section{Environmental Conservation Policy}

Sak Uwong Sak Uwit (SUSU) is a policy initiated by the Kendal Regency Government. The policy is stated in the Regional Regulation of Kendal District Number 3 of 2012 concerning Planting Trees for Prospective Brides and Gives Birth. The policy came into force on September 5, 2012. The 
Kendal Regency Government issued Provisions on the obligation to plant trees for brides and grooms.

Kendal District Regulation Number 3 of 2012 concerning Tree Planting for Prospective Brides and Gives Birth in Kendal Regency or known as the SUSU regional regulation (Sak Uwong Sak Uwit) is a juridical basis for the prospective bride and groom to give birth to plant trees. The bride and groom must plant the tree before marriage while the mother giving birth must plant the tree after giving birth with a maximum time limit of 30 days from the date of delivery. These regional regulations become regional regulations that are of public concern because these regional regulations fall into the category of regional regulations that care about the environment. Evidenced by this regulation, Kendal Regent in the period of 2010 - 2015, Widya Kandi Susanti, won the Gold Award from ENO (Environment Online) in the Pioneer of Tree Planting Regulation category.

ENO (Environment Online) is a global school network community for sustainable development (a global school network and web community for sustainable development) which was founded in 2000 in Finland (treeday.enoprogramme.org).

The theme of the environment becomes the main topic in this community by always campaigning continuously about the preservation of nature throughout the world. Already more than 10,000 networks from 150 countries have joined the agency since its establishment. The ENO program is coordinated and maintained by the ENO Program Association located in Joensu City. This institution has made concrete efforts to protect the environment such as planting 5,000,000 trees. ENO has also received several awards related to its programs (wikipedia.org). This regulation is motivated by a thought that one day humans will experience water crisis. Water will become an expensive rare item that is contested by humanity. Water will become a source of conflict because humans are fighting over these water resources (Interview with Widya Kandi, 2018).

What was conveyed by Widya Kandi Susanti was quite reasonable, considering that there were already many facts that showed the occurrence of social conflict caused by the seizure of water resources. Seizure of water sources between Subak (Arya dkk, 2013: 143) Yeh Gembrong with PDAM in 
Yeh Gembrong, Tabanan Regency, Bali, seizure of water resources between Jatiluwih Subak and private parties in Jatiluwih, Penebel, Tabanan Regency in Bali, and conflict over the seizure of Telaga Tanjung Tabanan Bali water (belebengong.id). In addition, in 2006, the United Nations Development Program (UNDP) report, which was formulated in the 2006 Human Development Report with the title "Beyond Scarcity: Power, Poverty, and the Global Water Crisis" (Beyond Power: Poverty, Poverty, and Water Crisis in full Global) illustrates that water shortages or water crises in various parts of the world have become a worrying disaster.

The report states that every country in the world faces different problems. The first problem facing these countries is that several countries face water and sanitation problems. Second, some of the poorest people in the world have to pay dearly to buy clean water. Third, the international community has failed to prioritize water and sanitation needs as the direction of the Millennium Development Goals. An important point of this problem is that the community experiences a shortage of clean water (UNDP, 2006: v-vi). The purpose of this regional regulation is to reduce the impact of global warming caused by carbon dioxide gas emissions and the greenhouse effect, and to empower rural communities to drive rural economic efforts. Breakdown of these objectives is to do greening in the region, empowering local communities, creating new jobs in the area, and driving regional economic efforts (Pemkab Kendal, 2012).

In addition to the possibility of a water crisis, global warming that occurred on this earth also became the basic argument made by the regional regulation. This problem requires efforts and solutions to overcome them. No matter how small the effort will be very helpful and beneficial to human life.

In the regional regulation there are two philosophical-sociological considerations, firstly, to reduce carbon dioxide gas emissions and the greenhouse effect as one of the causes of global warming, as a concrete manifestation of tackling global warming it can be done by planting trees for greening and to drive economic efforts and create jobs and for the development of micro, small, and medium enterprises for rural communities, it is necessary to open home industry business opportunities 
based on the management of superior natural resources of the village (Pemkab Kendal, 2012). In these considerations the argument for the establishment of the SUSU Regional Regulation is not only about environmental issues, but also from an economic perspective and overcoming poverty. The environmental problem in question is to reduce carbon dioxide emissions and global warming. While the economic problem in question is to drive the economy of the village community by creating jobs and creating village cooperatives (Pemkab Kendal, 2012).

Kendal District Regulation Number 3 of 2012 concerning Planting Trees for Prospective Brides and Gives Birth in Kendal Regency regulates specific issues and nuances of the environment, namely the obligation for every community who wants to get married and give birth to plant trees. The purpose of the regional regulation is to reduce the impact of global warming caused by carbon dioxide emissions and the greenhouse effect, and to empower rural communities to drive rural economic development (Pemkab Kendal, 2012). From this it seems clear that this regional regulation has two main objectives, namely to reduce the impact of global warming, and to drive the economy of rural communities. In more detail, the objectives of this regional regulation are as follows (Pemkab Kendal, 2012):

a. Greening in the area;

b. Empowering local communities;

c. Creating new jobs; dan

d. Driving regional economic ventures.

There are two groups that are targeted in this regional regulation, namely the bride and groom giving birth. Regarding the bride and groom, the regional regulation requires planting 2 trees before the bride and groom get married. As for mothers giving birth, this regional regulation requires planting one tree for mothers who give birth to their first child and second child, while mothers who give birth to a third child and so on are required to plant as many as 5 trees. For brides, the tree is planted before marriage, while for the cleaning mother, the tree is planted no later than 30 days from the date of birth (Pemkab Kendal, 2012).

Trees that can be planted, in the regional regulation, also mentioned criteria are trees that have hard trunks, trees that produce fruit, trees that 
have economic value, and trees that function as a shade (Pemkab Kendal, 2012). This is required considering that the main purpose of this regional regulation is to reduce the impact of global warming and drive the economy of rural communities so that the required tree species are also trees that can function ecologically or economically. This is in line with what was conveyed by the Regent of Kendal for the period of 2010-2015, Widya Kandi Susanti, that the plant that is distributed is a hard and fruitful plant so that there are many benefits to be gained (Interview with Widya Kandi, 2018).

Location or land that can be used to plant trees is in the yard of both the bride and groom and the mother giving birth. If the prospective bride or mother who gave birth does not have land to plant trees, then the tree can be planted in RTH (Green Open Space). The Green Open Space (RTH) is provided by the village / kelurahan government. RTH (Green Open Space) which is encoded can be in the form of bondo deso / ex bondo deso land (Edi, 2010: 50).

\section{Implementation of Regional Regulation of SUSU}

Based on interviews conducted with stakeholders related to the implementation of Kendal District Regulation Number 3 of 2012 on Planting Trees for Prospective Brides and Gives Birth in Kendal Regency or known as the Perda SUSU (Sak Uwong Sak Uwit) produces a relatively similar picture, namely regional regulations it was once held, but now the sound is no longer heard. Indeed, there are still subdistricts which until now still carry out these regional regulations namely Kaliwungu District, while others are no longer. The stakeholders interviewed were the Kendal District Head for the Period of 2010 - 2015, the Head of the Office of Religious Affairs in four sub-districts (Kendal District, Brangsong District, Kaliwungu District, and Kaliwungu Selatan District). Marriage Registration Assistant Officers $\left(\mathrm{P}_{3} \mathrm{~N}\right)$ formal, but the role and function is still there), and the bride and groom. The results of the interview show that the regional regulation is no longer effective. However the community is still very familiar with the local regulation. Many people still remember the SUSU (Sak Uwong Sak Uwit) regulations. And, in certain districts these regional regulations are still being implemented, such as in Kaliwungu District. 
The results of the interview the author to Acting. Head of the Office of Religious Affairs in Kendal District, H. Mochtar, because his definitive head is on leave to perform the pilgrimage, it can be illustrated that the regional regulation on the obligation to plant trees for brides and grooms giving birth now no longer works. The regional regulation can run well in the era of Kendal Regent leadership in the period of 2010-2015, Widya Kandi Susanti. At that time the regional regulation could run because there was emphasis and attention from the head of the local area by conducting socialization to the parties involved, including the environmental ranks of the Ministry of Religion Kendal in this case the Head of the Office of Religious Affairs (Interview with Mochtar, 2018).

At that time, the Head of the Office of Religious Affairs received socialization from the Kendal District Government, which was then followed up by the Head of the Office of Religious Affairs by disseminating information to the officers below, namely the Marriage Registration Assistant Officers $\left(\mathrm{P}_{3} \mathrm{~N}\right)$. As mentioned above, the official legal registrar of marriage $\left(\mathrm{P}_{3} \mathrm{~N}\right)$ is no longer available because the term of service expires in 2010 and is not extended anymore, but its existence in the community is still strongly felt and still plays a very significant role in helping to administer the administration of marriage. At that time, the Marriage Registrar $\left(\mathrm{P}_{3} \mathrm{~N}\right)$ in carrying out their duties was paid Rp. 25,000 per marriage. The Marriage Registration Assistant $\left(\mathrm{P}_{3} \mathrm{~N}\right)$ is the spearhead of the implementation of the tree planting obligation program for the bride and groom (Interview with Mochtar, 2018).

The Office of Religious Affairs in responding to the SUSU (Sak Uwong Sak Uwit) program is only an appeal because the Office of Religious Affairs in this case is a partner to run the program. The Office of Religious Affairs is structurally based under the Ministry of Religion in Kendal Regency, and is not instructive in nature with the Regional Government. In fact, those who have structural and instructive channels are village / lurah heads. Because of its appeal, its rigidity does not exist. In the Office of Religious Affairs which is important for complete requirements and obtaining signatures from the village / lurah head, the Office of Religious Affairs cannot refuse it. 
Some villages / kelurahan that can run are Banyutowo, Patukangan, Pekauman, and Pegulon. Whereas the kelurahan that are not running in Bandengan Kelurahan. As stated by Bangun Nidhom, the Marriage Registrar / P3N Registrar of Bandengan Village stated that in Bandengan Village the tree planting program for the bride and groom did not work because the Marriage Registrar / $\mathrm{P}_{3} \mathrm{~N}$ Officer did not socialize to the bride. He did not socialize to the bride and groom because the government itself did not carry out its obligations, namely providing land and preparing certificates. Bandengan is a village with limited land, so if the government does not provide land, it will be difficult for the bride and groom to plant the tree. In principle, the Registrar of Marriage Registration/ $\mathrm{P}_{3} \mathrm{~N}$ does not object to implementing the program, but with a note that the government must provide land in advance (Focus group discussion, 2018). He also said that basically the residents also did not mind if asked to plant trees when they were going to get married. Moreover, trees in Bandengan do not have to buy, for example, pine trees, mangroves (bakau) (Saparinto, 2007: 2627), and others. These tree species can be found everywhere and do not have to buy, even though the tree is not included in the tree recommended by Kendal District Regulation No. 3/2012 concerning Planting Trees for Prospective Brides and Gives Birth in Kendal Regency. Trees recommended by the regional regulation are fruiting hard trees such as mango, guava, sapodilla, jackfruit, and others. However it would not hurt if it was planted pine and mangrove trees. In fact, this is the right tree to be planted in Bandengan Village whose territory is located on the north coast of Kendal Regency. In coastal areas, these plants are very useful to protect the land from the threat of abrasion and to hold back water from preventing intrusion.

Different from what happened in Bandengan Kelurahan are Banyutowo Kelurahan, Pegulon Kelurahan, Pekauman Kelurahan, and Patukangan Kelurahan. In Banyutowo Urban Village, as conveyed by Badiudin, Marital / $\mathrm{P}_{3} \mathrm{~N}$ Marriage Registry Assistant Officer, the tree planting program for prospective brides can run well. The key is that he always socializes to the bride and groom who will hold a wedding about the obligation to plant trees for the bride and groom. In fact, information about the program is very familiar in the community. There is a kind of shared knowledge in the 
community if you want to get married you have to plant trees. Such knowledge can occur because they have been informed too often about the Sak Uwong Sak Uwit (SUSU) program. According to him hundreds of trees have been planted by the bride and groom, but the exact number does not know because it is not well documented about that number (Focus group discussion, 2018).

To make the program a success, he has direct communication with the plant seed seller. He advised the sellers of plant seeds if the bride was buying the bride, the price would be lowered. And it did work, the price given to the bride and groom was below the market price. In fact, as an effort to succeed the program, he asked to be sent plant seeds to be placed in his home. The bride and groom do not need to bother going to the sellers of plant seeds, just buy the seeds at the brother's house Badiudin (Married Assistant Registrar / $\left.\mathrm{P}_{3} \mathrm{~N}\right)$. He gets the price of plant seeds which is cheaper than the market price. Then he sells the seeds of these plants at prices according to the market. The rest of the price is used as a cost to plant these plants because not all prospective brides want to plant trees that have been purchased.

The Sak Uwong Sak Uwit (SUSU) program was indeed able to run at that time, 2015. This can be confirmed by the opinion of the bride and groom. As stated by Miftah Fadlullah, from Kendal District who was married in 2015 that she was recommended by the Marriage Registration Assistant $\left(\mathrm{P}_{3} \mathrm{~N}\right)$, Badiudin, to plant trees. Miftah said that usually before marrying plant trees. By encouraging tree planting by the $\mathrm{P}_{3} \mathrm{~N}$ the bride and groom do not mind and follow what is recommended by the officers because it has become a habit in the community based on information developed in the community that the prospective replacement is advised to plant trees. The response of the bride and groom at the time it was recommended to plant trees had no objections because the program was good for greening and the fruit could be beneficial. In addition, the tree recommended for planting is not burdensome. The plants to be planted were also not determined to be left to the bride and groom to plant what trees. The tree that was planted when he was getting married was a mango 
tree. Moreover, this program is for greening the environment. Precisely this is a very good program to be implemented (Interview with Fadlullah, 2018).

In contrast to what was conveyed by Miftah, the mushonif who married in 2017 said that when he was going to get married, he did not get information about the obligation to plant trees for the bride and groom. He learned this information from the community that if he wanted to get married he was told to plant trees. But because there was no suggestion from the official, he did not plant trees. If the officer advised him to plant a tree, he would plant a tree. He also told me, once a neighbor, his name was sobirin, when he was about to get married it was advisable to plant a tree, and the tree planted at that time was a mango tree. He while showing the tree planted sobirin. Currently the tree is large and has been bearing fruit (Interview with Mushonif, 2018).

Agus Riyanto, from Brangsong Subdistrict who was married in 2015, said that he was not ordered or told by officers to plant trees when he got married. According to him, this program Sak Uwong Sak Uwit (SUSU) is very good. The program is very useful to preserve the environment so that the environment remains cool, not hot, and besides that the fruit can also be utilized. He felt no objection if he was told to plant trees as long as the trees that were claimed were not rare and the prices were still affordable. If for example a mango tree is planted, the price is still very affordable and not burdensome (Interview with Riyanto, 2018).

Likewise, the explanation from the Head of the Office of Religious Affairs in Brangsong District, Sudardi, which tells us that the Sak Uwong Sak Uwit (SUSU) program could work. He told me in the yard of the Office of Religious Affairs where he had worked, that is in Weleri District filled with plants given by the bride and groom. But the conditions are different from now. Now the program is no longer running. He also said that this program was very good and should be supported by all parties (Interview with Sudardi, 2018).

In contrast to the Brangsong District Religious Affairs Office, the Head of the Kaliwungu District Religious Affairs Office, Adib Muhlasin said that in Kaliwungu District the Sak Uwong Sak Uwit (SUSU) program is still ongoing. Some even include receipts of proof of buying plants. This can 
happen because the officers in the field, namely the Registrar of Marriage Registration $\left(\mathrm{P}_{3} \mathrm{~N}\right)$ are still socializing to the bride and groom (Interview with Muhlasin, 2018). This was justified by Komari as the Marriage Registrar Assistant ( $\mathrm{P}_{3} \mathrm{~N}$ ) of Sarirejo Kaliwungu Village. He said if there were brides, they had to show receipts as proof of buying plants (Interview with Komari, 2018). According to Adib Muhlasin, the inclusion of proof of purchase of plants in the marriage file, made a special concern because the principle of marriage is low cost, even free, but if included receipts to buy plants, the worry is included in the cost of marriage. So that now no longer required to include proof of buying trees (Interview with Muhlasin, 2018).

In South Kaliwungu it is different again, now the bride and groom are no longer burdened with planting trees. The concern that arises is that the expectation of the cost of the marriage is zero rupiah, but if it is burdened with other requirements it becomes expensive. This is what is worried by the Head of the Office of Religious Affairs in Kaliwungu Selatan District, Jazuli (Interview with Jazuli, 2018).

Meanwhile, pregnant women who check with village midwives, all did not get information about the obligation to plant trees for mothers giving birth. Because they did not get information about the tree planting program for mothers who gave birth they also did not do that. Although in fact they do not mind the program. Suppose they are told or encouraged to plant trees they feel they don't mind.

As revealed by Tuti Maryati, a resident of Banyutowo Village, Kendal District, gave birth in 2016. She stated that when she was pregnant, she checked her contents to the village midwife, Mrs. Puji, and the obstetrician Junda. He checks with the village midwife once a month and when the womb is approaching birth, the examination is carried out more routinely, one month twice. During the examination of the womb in the midwife, he never got direction or advice to plant trees. The midwife never told her to plant a tree as an implementation of the Sak Uwong Sak Uwit (SUSU) program launched by the Kendal District Government. Direction obtained from village midwives is limited to the health of pregnant women and the condition of the fetus in the womb (Focus group discussion, 2018). 
According to Tuti Maryati, the program was very good but because of her ignorance, she did not implement the program. If at that time it was recommended by the village midwife, he would run the program. He felt no objection to the need to plant trees for mothers giving birth. Moreover, trees planted are trees that bear fruit and may be planted in their own yards. Because it is planted in the yard itself, later if the tree bears fruit can be harvested and used by the tree planter himself. In addition, also for greening so that the environment looks cool, fresh, and not hot. Because the number of plants in the environment will make the environment more beautiful (Focus group discussion, 2018).

In line with what was conveyed by Dewi Murdianasari who gave birth to her second child in 2018. When she was pregnant, she checked with Mirza doctors, health centers, and the field of ketapang, indri mothers. When checking the womb he is not recommended at all for planting trees. $\mathrm{He}$ suggested that, if he didn't mind to plant trees when giving birth later. $\mathrm{He}$ said that the senadda was advised to plant a tree, so he felt no objection and would gladly plant the tree. The tree to be planted is a mango tree whose purpose is not only to reforest the fruit but also enjoy it (Focus group discussion, 2018).

In line with Dewi Murdianasari, Khariroh, the mother who gave birth in 2015 also said that during her pregnancy check, she never got information or socialization from the midwife where she was examined. She said that during her pregnancy check-up she never received advice and direction from the midwife to plant six trees if she had given birth. Midwives only provide guidance related to the health of pregnant women and the unborn child. Midwives only suggest eating healthy and nutritious foods so that they are strong and healthy (Focus group discussion, 2018).

From the explanation of Ms. Neneg Purwaniko, the woman giving birth in 2017, also said that during the midwifery check, she was never given any instructions about planting trees for the mother giving birth. The information delivered focuses on the health of the mother and baby in the womb. in principle, he does not object to the program launched by the government because the program is not burdensome and good for the environment. What he feels is that the weather is getting hotter, so the 
greening through the need to plant trees for mothers giving birth to their first and second children, as well as five trees for mothers giving birth to third children will help reduce the impact of global warming. If the effects of global warming can be reduced or reduced the weather will be cooler. In addition, the fruit produced can be enjoyed both individually and together (Focus group discussion, 2018).

Likewise, what was delivered by Ikha Solekhah was that during the midwifery check in the village midwife, the midwife had never been told to plant trees. As mothers check for pregnancy, midwives provide information about the health of pregnant women and their unborn babies. The results of the author's interview with the mother who gave birth stated that the mother who gave birth did not get information about it, so she did not implement the program, which is planting trees for mothers who gave birth. Tuti Maryati also said that if she was encouraged to plant trees after giving birth then she felt no objection and instead responded positively to the government program. According to him, the government program was a good program and he accepted it well if it was recommended to implement the program (Focus group discussion, 2018).

When the writer confirmed to the midwife in question, that is, Puji Astuti, she confirmed that the midwife never told pregnant women who checked to plant trees. Instead he said was not to plant the tree intended for people who want to get married. He also said that he never got any information about planting trees for mothers giving birth. If he gets socialization about the program, he will certainly socialize it to pregnant women who check up. According to him, this program is very good for preserving the environment, so that the air is cool and not hot (Interview with Astuti, 2018).

\section{Community Perception of SUSU Policy}

Although not all brides and grooms give birth to the Sak Uwong Sak Uwit (SUSU) policy, but they respond positively to the program. Actually they did not object to the policy. The policy made is not burdensome to the community because what is purchased is a tree seedlings that bear fruit. 
People in this case think futuristic. They can accept the arguments built by the Sak Uwong Sak Uwit policy, namely, to reduce the impact of global warming and revive the economy of rural communities, but the community better understands that planting trees benefits a lot for greening. With green air becomes cool. In addition, trees that have been fruitful can be used individually or together.

From the Focus Group Discussion (FGD) to interviews conducted with the Regent of Kendal for the period 2010-2015, Widya Kandi Susanti, Head of the Office of Religious Affairs (KUA) in Kendal District, Brangsong, Kaliwungu, South Kaliwungu, Midwives Village, the community of both brides and mothers giving birth, they responded positively to the policies made by the local government. Instead, they regretted why the information did not reach them, especially mothers giving birth.

If this program can be implemented optimally, the positive impact caused is enormous. From the available data, the number of brides in Kendal Regency for four years starting in 2015-2018 was 33,441. this much amount if all implement the policy of Sak Uwong Sak Uwit (SUSU) then 66,882 trees will be planted. One year, the Kendal community can plant 16,720 trees, every month they can plant 1,393 trees, and every day they can plant 46 trees. This amount is only for prospective brides only. The number of babies born in Kendal Regency since 2015-2018 was 56,773 babies. If all mothers gave birth to plant trees, they would plant 56,773 trees for four years. 14.193 trees will be planted annually, 1,182 trees will be planted every month and 39 trees will be planted every day.

When combined with the bride and groom giving birth, 123,655 trees will be planted for four years, 30,913 trees will be planted annually, 2,576 trees will be planted every month and 85 trees will be planted every day.

With the number of trees planted every day, certainly can realize what is expected from the enactment of the local regulation that is reducing the impact of global warming. If this program can be carried out according to available data, then every year the Kendal community can plant an area of 3 $\mathrm{km}^{2}$ assuming the distance of planting trees is $10 \mathrm{~m}$. Thus $1 \mathrm{~km}^{2}$ needs 10,000 trees, so if one year can plant 30,913 trees then $3 \mathrm{~km}^{2}$ can be planted every year. In the case of Kendal Regency's land area, the area of non- 
agricultural land is $235.75 \mathrm{~km}^{2}$, so it takes 78 years to be able to fill the existing land with trees. This means that vacant land is actually still very broad if it is able to think comprehensively and cross-sectorally administratively without being limited to village / urban boundaries.

\section{Conclusion}

From the results of research and discussion that have been submitted, it can be concluded as follows: Regional Regulation of Kendal District Number 3 of 2012 concerning Tree Planting for Prospective Bride and Groom Giving Birth in Kendal Regency or known as Regional Regulation of Sak Uwong Sak Uwit (SUSU) in substance is very substance good because of its future-oriented perspective that is wanting to contribute in reducing the impact of global warming and wanting to advance the economy of rural communities.

Implementation of Kendal Regency Regional Regulation Number 3 of 2012 concerning Planting Trees for Prospective Brides and Gives Birth in Kendal or other known as the Regional Regulation of Sak Uwong Sak Uwit (SUSU) as a whole has been implemented but not yet maximized but for mothers giving birth did not take place because the socialization did not reach village midwives let alone mothers giving birth, Community perception of Kendal District Regulation Number 3 of 2012 Concerning Tree Planting for Prospective Brides and Gives Birth in Kendal District or known as Regional Regulation of Sak Uwong Sak Uwit (SUSU) is very positive because they know the benefits of planting trees in addition to general benefits also personally beneficial.

Kendal District Regulation Number 3 of 2012 Concerning Tree Planting for Prospective Brides and Gives Birth in Kendal District or known as Regional Regulation of Sak Uwong Sak Uwit (SUSU) has been able to move the community to care for the environment by planting trees, but it has not yet become a living law in the community (living law) because so there is no supervision from the government or institutions related to the habit of planting trees to be stopped.

Community perception of Kendal District Regulation Number 3 of 2012 Concerning Tree Planting for Prospective Brides and Gives Birth in Kendal 
District or known as Regional Regulation of Sak Uwong Sak Uwit (SUSU) is very positive because they know the benefits of planting trees in addition to general benefits also personally beneficial, Kendal District Regulation Number 3 of 2012 Concerning Tree Planting for Prospective Brides and Gives Birth in Kendal District or known as Regional Regulation of Sak Uwong Sak Uwit (SUSU) has been able to move the community to care for the environment by planting trees, but it has not yet become a living law in the community (living law) because so there is no supervision from the government or institutions related to the habit of planting trees to be stopped. [w]

\section{Noted:}

Bungalow is a house that is built all in one level.

Joint venture is an agreement between two or more parties to cooperate in an activity. Often, a joint venture is carried out if the companies through complementary technology want to create goods or services that will strengthen each other's position. Judging from the current implementation, there is a form of joint venture cooperation that forms a new legal entity, so therefore the joint venture is divided into two parts, namely: 1) Temporary joint ventures, namely business cooperation between foreign investors and domestic investors by not forming a new legal entity. 2) Permanent joint ventures, namely business cooperation between foreign investors and domestic investors who form new legal entities.

Subak is a Balinese water management organization with a simple irrigation tool but recognized as having high social resilience. This organization is not merely related to the elements of engineering, but is of a social-technoreligious nature. The politics of mass tourism development that spurred the pace of development of infrastructure and public facilities with the use of natural resources including land and water caused massive land use and water conversion, threatening the sustainability of subak. This research aims to study the political dynamics of the economy of water resources and 
their impact on subak institutions which are one of the main pillars of development in Bali. Research with this qualitative method finds that: (1) the politics of water economy is very dynamic involving a variety of local, national, global actors with different interests and ideologies; (2) the priority of mass tourism in Bali has led to a battle of access to water resources with immaterial and material conflicts; (3) systematic development-oriented agricultural development has reduced subak social capital; (4) the politics of development and the production of state power (laws and policies) systematically weakens the production of power of the subak community (awig-awig and perarem) so that the existence of subak as an irrigation organization which is the basis of strength to support food security is increasingly pressed.

Crooked land is land that is owned by the customs themselves to be given to the village head and village officials concerned. There are two types of crooked land, namely crooked land owned by traditional villages and land purchased by adat to be given to village officials. Crooked land in the agrarian system on Java Island is cultivated land belonging to the village. The land cannot be traded without the consent of all villagers but may be leased by those who are given the right to manage it. According to the use of crooked land is divided into 3 (three) parts, namely: first, Land L really, that is the land that belongs to the village apparatus / pamong as compensation for salaries that they did not receive, secondly, the Village Cash Land, namely land managed by the instrument/pamong active villages to fund infrastructure development or village needs in general, and thirdly Land Pengarem-Arem, which is the land that belongs to village officials who have retired or retired to work on as old age security and after death the land is returned to management to the village government.

Mangroves are forest vegetation that grows between tidal lines, plants that live between the sea and land. This plant has the function of keeping the coastline stable, protecting the coast and riverbanks from erosion or abrasion, reducing or absorbing strong winds from the sea to the land, reducing and holding tsunami storms, holding sediment periodically until new land forms, as buffer zone for intrusion or seawater seepage to the ground, or as a saltwater filter into fresh water, as a place for recycling to 
produce oxygen and absorb carbon dioxide, as a treatment for waste materials resulting from industrial pollution and ships at sea, as an area spawning ground or nursery ground for shrimp, fish, crabs, shellfish, and so on which as adults will return to shore, areas for protection, nesting, and breeding for birds and other animals, as a source of germplasm and genetic sources, as natural habitats for various types of terrestrial and marine biota.

\section{Reference}

Edi, Kuncoro. 2010. Peralihan Tanah Bengkok dan Akibat Hukumnya (Studi Kasus Putusan PN Boyolali Nomor 51/Pdt.G/1999/PN.Bi). Tesis. Semarang: Universitas Diponegoro.

Focus Group Discussion (FGD) 'Menanam pohon bagi ibu melahirkan', 20 Agustus 2018.

Focus Group Discussion (FGD) 'Menanam pohon bagi calon pengantin', 23 Agustus 2018.

Hanitijo, Ronny. 1990. Metodologi Penelitian Hukum dan Jurimetri. Jakarta: Ghalmia Indonesia.

http://treeday.enoprogramme.org/ diakses pada 14 Agustus 2018.

https://balebengong.id/kabar/ketika-mata-air-jadi-air-mata.html?lang=id, diakses pada 16 September 2018.

https://en.wikipedia.org/wiki/Environment_Online diakses pada Agustus 2018

Badan Pusat Statistik Kabupaten Kendal. 2018. Kabupaten Kendal dalam Angka 2018.

Murdiyarso, Daniel. 2005. Sepuluh Tahun Perjalanan Negosiasi Konvensi Perubahan Iklim. Jakarta: Kompas.

Oxford University. 2009. Oxford Learner's Pocket Dictionary. Oxford: Oxford University Press.

Panjaitan, Hulman, and Sianipar, Anner Mangatur. 2008. Hukum Penanaman Modal Asing. Jakarta: Ind Hill Co Original. 
Peraturan Daerah Kabupaten Kendal Nomor 3 Tahun 2012 Tentang Penanaman Pohon bagi Calon Pengantin dan Ibu Melahirkan di kabupaten Kendal.

Saparinto, Cahyo. 2007. Pendayagunaan Ekosistem Mangrove Mengatasi Kerusakan Wilayah pantai (Abrasi) Meminimalisasi Dampak Gelombang Tsunami, Semarang: Dahara Prize.

Tarigan, Herlina, dkk., 2013. "Persaingan Akses Sumber Daya Air di Yeh Ho, Tabanan, Bali”, Jurnal Agro Ekonomi, 2 (31): 143-159.

United Nations Development Programme (UNDP). 2006. Human Development Report 2006 Beyond Scarcity: Power, Poverty and The Global Water Crisis, New York: UNDP

Interview with Agus Riyanto, 11 Agustus 2018.

Interview with Widya Kandi Susanti, 3 Agustus 2018.

Interview with Sudardi, 22 Agustus 2018.

Interview with Jazuli, 23 Agustus 2018.

Interview with Adib Muhlasin, 23 Agustus 2018.

Interview with Komari, 23 Agustus 2018.

Interview with Miftah Fadlullah, 13 Agustus 2018.

Interview with Muhammad Mushonif, 10 Agustus 2018.

Interview with Mochtar, 5 Agustus 2018.

Interview with Puji Astuti, 21 Agustus 2018.

www.kendalindustrialpark.co.id. diakses 10 September 2018. 